Neuro/mages

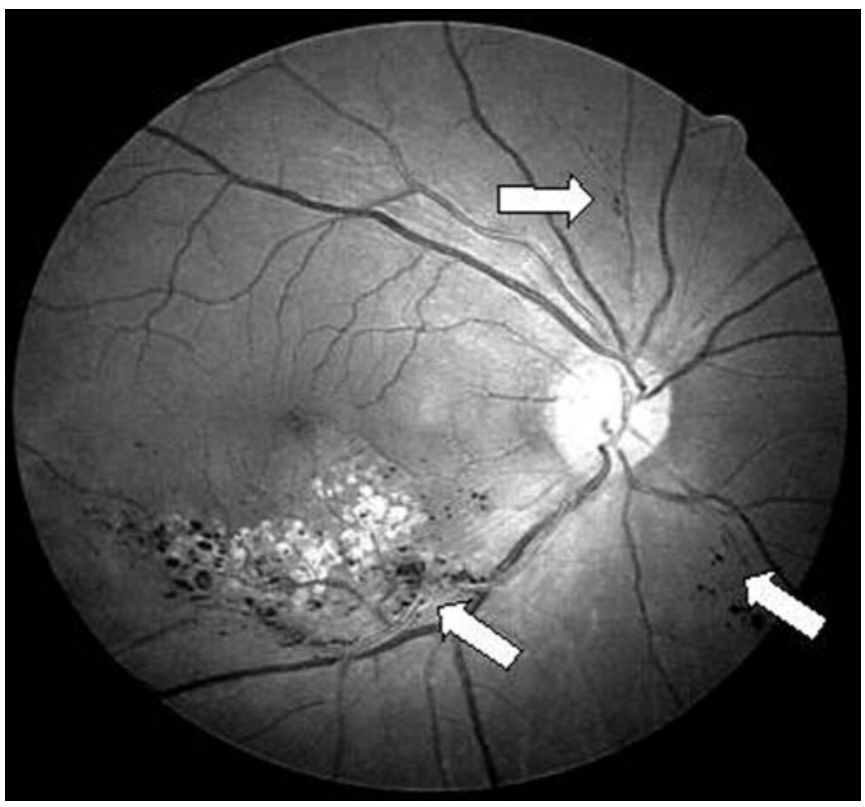

Figure 1. Ophthalmoscopy shows retinal angiomas of the right eye after laser photocoagulation.
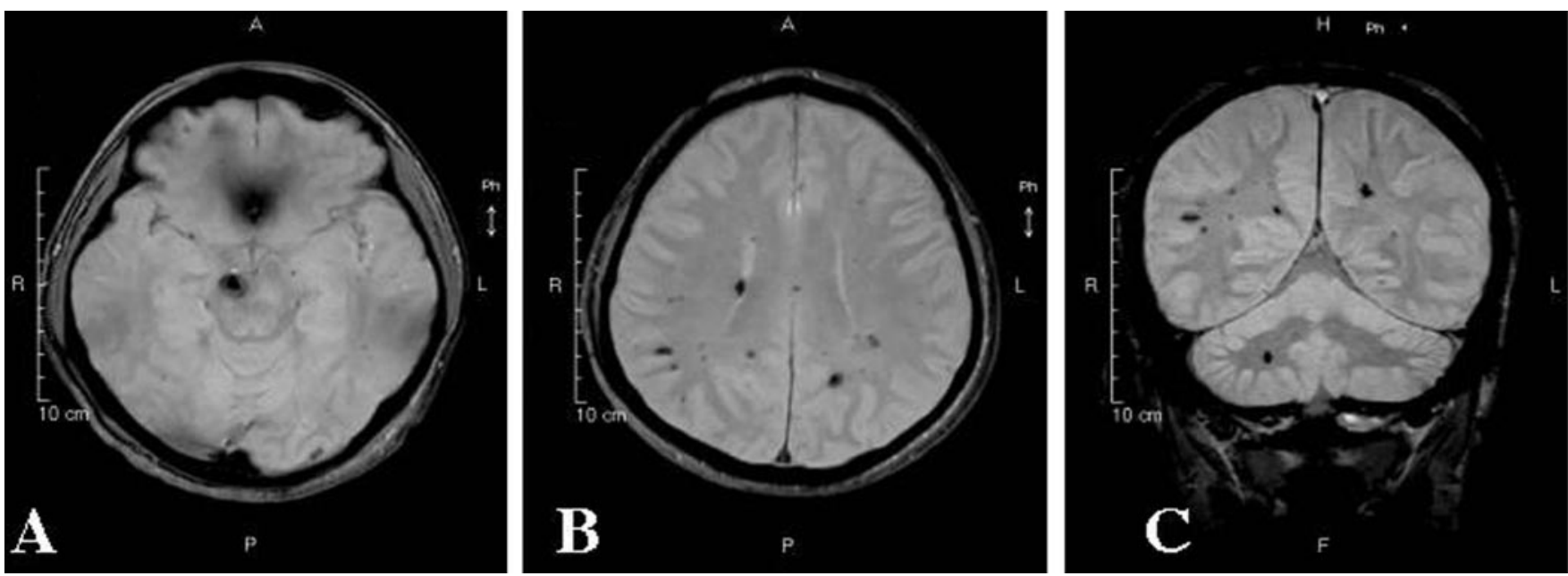

Figure 2. (A, B) Axial and (C) coronal T2*-weighted gradient echo MRI shows multiple signal loss lesions in the brain.

\section{Familial cavernous angiomas}

K. Ikeda, MD, PhD; K.-i. Hosozawa, PhD; H. Kashihara, PhD;

S. Kuratomi, PhD; J. Kumazawa, PhD; M. Shioikari, PhD;

A. Kuwajima, $M D$; $M$. Tamura, $M D$; and $Y$. Iwasaki $M D$,

Tokyo, Japan

A 49-year-old man had a physical check-up, including brain MRI. At 19 years of age, retinal hemorrhage was pointed out. He received laser photocoagulation therapy in the right eye. A family history suggested that his 74-year-old mother had angiomas in the brain, retina and skin of the left thigh. She developed cerebral hemorrhage after treatment with an anti-thrombotic agent in ischemic stroke. A 20-year-old son had also multiple angiomas in

Address all correspondences and reprint requests to Dr. Ken Ikeda, Department of Neurology, PL Tokyo Health Care Center, 16-1, Kamiyamacho, Shibuyaku, Tokyo 150-0047, Japan; e-mail: keni@pl-tokyo-kenkan.gr.jp the brain. Physical examination showed angioma in the skin of the left foot. Ophthalmoscopy showed angiomas in both fundus oculi (figure 1). Brain T2*-weighted gradient echo MRI revealed multiple round signal loss areas in the brain stem, cerebellum, and cerebral white matter (figure 2). Familial cerebral cavernous angiomas are reported in large Hispanic and French families. ${ }^{1-2}$ Our Japanese three-generation family indicates that cerebral, retinal, and cutaneous cavernous angiomas were inherited as an autosomal dominant trait. Gene mutation of cerebral cavernous malformations is currently being analyzed.

1. Mason I, Aase JM, Orrison WW, Wicks JD, Seigel RS, Bicknell JM Familial cavernous angiomas of the brain in a Hispanic family. Neurology 1988:38:324-326.

2. Labauge P, Brunereau L, Laberge S, Houtteville JP. Prospective follow-up of 33 asymptomatic patients with familial cerebral cavernous malformations. Neurology 2001;57:1825-1828. 


\section{Neurology}

Familial cavernous angiomas

K. Ikeda, K.-i. Hosozawa, H. Kashihara, et al.

Neurology 2005;64;163

DOI 10.1212/01.WNL.0000142982.80308.D9

This information is current as of January 10, 2005

\section{Updated Information \&} Services

Supplementary Material

References

Subspecialty Collections

Permissions \& Licensing

Reprints including high resolution figures, can be found at: http://n.neurology.org/content/64/1/163.full

Supplementary material can be found at: http://n.neurology.org/content/suppl/2012/04/16/64.1.163.DC1

This article cites 2 articles, 2 of which you can access for free at: http://n.neurology.org/content/64/1/163.full\#ref-list-1

This article, along with others on similar topics, appears in the following collection(s):

MRI

http://n.neurology.org/cgi/collection/mri

Other cerebrovascular disease/ Stroke

http://n.neurology.org/cgi/collection/other_cerebrovascular_disease_st roke

Information about reproducing this article in parts (figures,tables) or in its entirety can be found online at:

http://www.neurology.org/about/about_the_journal\#permissions

Information about ordering reprints can be found online:

http://n.neurology.org/subscribers/advertise

Neurology ${ }^{\circledR}$ is the official journal of the American Academy of Neurology. Published continuously since 1951, it is now a weekly with 48 issues per year. Copyright . All rights reserved. Print ISSN: 0028-3878. Online ISSN: 1526-632X.

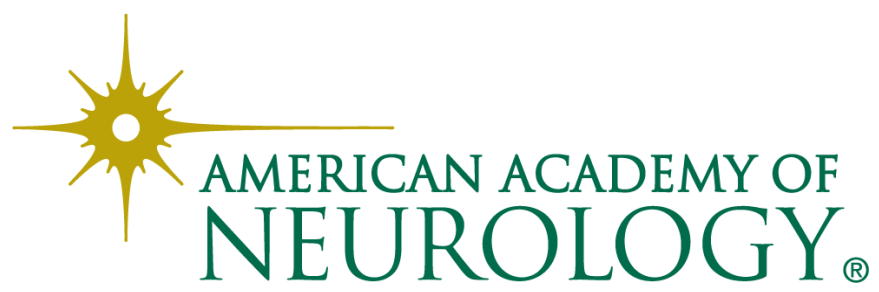

